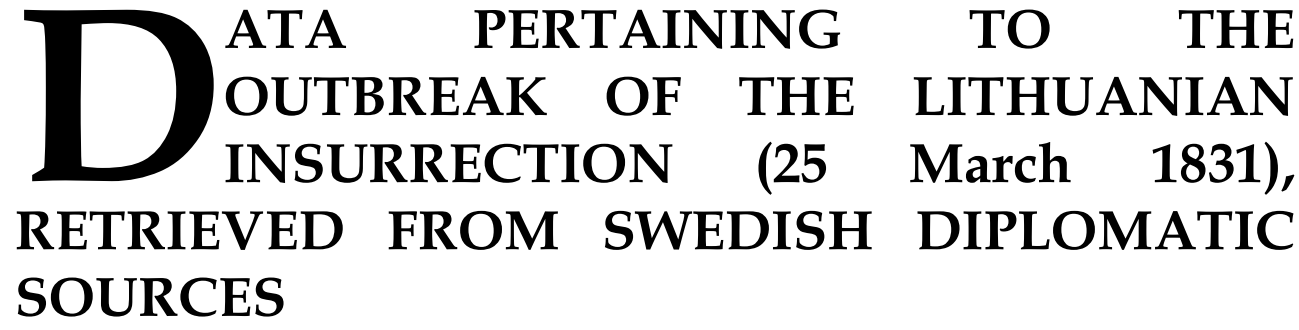

\title{
Veniamin Ciobanu
}

“A. D. Xenopol” Institute of History, E-mail:
veniamin@xenopol.iasi.astral.ro

\section{Acknowledgments}

The article is based on a paper presented at the Second International Conference of the Romanian Association for Baltic and Nordic Studies: Black Sea and Baltic Sea Regions: Confluences, influences and crosscurrents in the modern and contemporary ages, at Târgovişte, May 20-22, 2011.

\begin{abstract}
:
Similarly to the Polish insurrection of November 1830, the Lithuanian one, occurring in March 1831, retained the attention of the Swedish diplomacy from the very beginning. This was made possible, in the first place, by the fact that the events were connected by a strong link of causality, in the sense that they aimed at severing Poland and Lithuania from the political-institutional system of the Russian Empire and at reconstituting the old one, i.e. the Polish-Lithuanian Union. But the latter's victory would have first resulted in the radical upheaval of the ratio of forces in North-Eastern Europe, which could have also affected the Swedish-Norwegian political-institutional system, since it was assumed that the Norwegians would not have spared any time in following the Lithuanian and Polish example by denouncing the personal union with Sweden. Moreover, the revolutionary wave sweeping over Europe in 1830 was not one to avoid Sweden. Unlike other areas, the Swedes that opposed King Karol XIV Jan's government went no further than to criticise it, despite the fact that both the criticism and the programme of the opposition kept increasing in boldness. The Swedish diplomacy therefore approached the issue of the Polish and Lithuanian insurrections from the same perspective, taking particular care to observe their evolution, placing itself in a position of reserveless condemnation of such behaviour. The documents transcribed in the following pages are the diplomatic reports of N. Fr. Palmstjerna, the chargé d'affaires of Sweden in Petersburg, and were selected from the Sveriges Riksarkivet, Kabinettet/UD Huvudarkivet, E2D, 702, the Petersburg fund, 1821, Jan.-iuni. They sometimes contain very detailed information pertaining to the early phase of the Lithuanian insurrection. By introducing them to the academic circuit, we express our hope that they will contribute to the expansion of the
\end{abstract}


research horizon of the history of North-Eastern Europe from the first half of the 19 th century.

\section{Rezumat:}

Ca şi insurecția din Polonia, izbucnită în luna noiembrie 1830, cea din Lituania, declanşată în luna martie 1831, a reținut, chiar de la început, atenția diplomației suedeze. În primul rând, pentru că ambele evenimente erau într-o strânsă legătură de cauzalitate, în sensul că urmăreau desprinderea Poloniei şi a Lituaniei din sistemul politico-instituțional al Imperiului Rusiei şi reconstituirea celui vechi, anihilat de ocupația rusă, anume Uniunea Polono-Lituaniană. Or, victoria acestora ar fi produs o răsturnare radicală a raportului de forțe din Europa de Nord-Est, în primul rând, şi care ar fi putut afecta şi sistemul politicoinstituțional suedo-norvegian, de vreme ce era de presupus că norvegienii nu ar fi intârziat să ia exemplul polonezilor şi lituanienilor şi să denunțe uniunea personală cu Suedia. In plus, valul revolutiilor care s-au declanşat în Europa în anul 1830 nu a ocolit nici Suedia. Spre deosebire de alte zone, suedezii care se opuneau guvernării regelui Karol al XIV-lea Jan s-au limitat doar la critici la adresa acesteia, deşi atât criticele, cât şi programul opoziției deveneau tot mai îndrăznețe. Aşadar, din această perspectivă a abordat şi diplomatia suedeză problema insurecților din Polonia şi din Lituania., ale căror evoluții le-a urmărit cu o atenție deosebită şi față de care s-a postat pe poziția condamnării lor, fără rezerve. Documentele reproduse in aceste pagini sunt rapoartele diplomatice ale lui N. Fr. Palmstjerna, însărcinatul cu afaceri al Suediei la Petersburg şi au fost selectate din Sveriges Riksarkivet, Kabinettet/UD Huvudarkivet, E2D, 702, fond Petersburg, 1821, Jan.-iuni. Ele conțin informații, uneori foarte detaliate, referitoare la faza de inceput a insurectiei din Lituania. Punându-le în circuitul ştiințific, ne exprimăm speranța că ele vor contribui la lărgirea orizontului de cercetare a istoriei Europei de Nord-Est, din prima jumătate a secolului XIX.

Keywords: Russia, Poland, Lithuania, insurrection.

The period following the Congress of Vienna (1814-1815) was characterised by efforts to restore the continental political system as it had been before the outbreak of the French revolution of 1789. The two 'champions' of this tendency were Russia and Austria. Tsar Alexander I and, later on, his successor, Nicholas I, thought of themselves as the promoters of the antirevolutionary and antidemocratical battles, as well as the keepers of the principle of monarchic legitimacy. They were seconded by the chancellor of Austria, Klemens Wenzel Lothar Napomuk, von Metternich Winneburg, the public figure that embodied the restauration policy. His political system mercilessly took aim against all things connected to the revolution, against the idea of nationality, as well as any tendency to modernise the constitutional principles. He thus defended the 
interests of the Habsburg Empire, whose existence was threatened by the proliferation of the national and democratic ideas ${ }^{1}$.

The Greek National Liberation Revolution that broke out in 1821 also contributed to the undermining of the monarchic legitimity system, however, but without surpassing the extent of a local event. On the other hand, the revolution in Paris of July 1830, resulting in the removal of the Bourbon dynasty from the throne of France, determined a serious crisis in the system. As is known, the restoration of the Bourbons was the work of immigrants interested to restore the old nobiliary privileges. But the revolution of July, bringing to power the rich bourgeoisie, proved once more that, as had been the case with the English Dynasty of the Stuarts, removed from the throne in 1649 in well-known circumstances and restored in 1660 just to be removed once more due to the so-called 'Glorious Revolution' of 1688, a restored monarchy could not last for long 2 .

Under the direct influence of the French revolution of 30 July, the opposition against the monarchic legitimacy principle grew stronger throughout Europe. The first results were recorded within the United Kingdom of the Netherlands, a 'child' of the Vienna Congress, formed through the union of Holland with Belgium and Luxembourg. On 25 August 1830, a national and bourgeois revolution broke out in Brussels, resulting in the proclamation of Belgium's independence on 4 October of the same year. Almost at the same time another insurrection emerged, the one in Poland of November 1830, preventing Tsar Nicholas I from sending troops to France in order to stifle the revolution. However, this provided him with the long awaited for opportunity to liquidate the semiautonomous status of the Kingdom of Poland created by the Congress of Vienna in 1815. Shortly afterwards, the Italian Revolution took place, although it was soon smothered by Austrian troops ${ }^{3}$.

On this background a new insurrection debuted in North-Eastern Europe, i.e. that of Lithuania, on 25 March 1831. As the one in Poland, the insurrection in Lithuania was a reaction to the repression unleashed by the tsarist authorities against the liberal movements starting with the year 1820 . In their proclamations, the participants in the insurrection denounced the severance of Lithuania from the Russian Empire and its union with the Kingdom of Poland. Still, there was no common point of view of the

\footnotetext{
${ }^{1}$ Hermann Bamhauer et al., bearbeiter, Illustrirte Weltgeschichte (München: Südwest Verlag, n.d.), 375.

2 Ibid., 379.

${ }^{3}$ Ibid., 379-380.
} 
insurgents regarding the political future of Lithuania, since some of them were pleading for the creation of an independent Lithuanian state 4 .

In the initial stage of the insurrection there was no unitary leadership, but the insurgents took advantage of the absence of the Russian army, which was in Poland countering the revolution taking place there, and obtained control of almost the entire territory of Lithuania. Vilnius and Kaunas, however, remained under the control of the Russian authorities. In May 1831, the leadership of the insurrection was taken over by A. Ilgaudas, while the Polish insurgents started providing regular support to the Lithuanians. An interim Polish government was constituted in Lithuania at Ilgaudas's general quarters, after which the insurgents succeeded in occupying Kaunas, but lost the battle for Vilnius due to the fact that they were overwhelmingly outnumbered by the Russian troops. Consequently, the insurgents started to withdraw, but during the withdrawal A. Ilgaudas was shot by an officer under his command. As a result, the mentioned interim government was dissolved and the insurgent administration in the region was abolished. The consequences were soon to follow: the Russian control became stronger, the inhabitants were forced to pay requital, the taxes grew and the military forces of the Kingdom of Poland were dissolved. The Kingdom of Poland lost its autonomy, becoming a Russian guberniyia, the active participants to the insurrection were the victims of retaliation, including the closing down of the University of Vilnius, in 1832.

The revolutionary wave that swept Europe in 1830 did not steer clear off Sweden. Unlike what happened in other areas, the Swedes who opposed king Karol XIV Jan's governing did not go further than to criticize him, although both the criticism and the programme of the opposition became bolder and bolder. Thus, in May 1830, one of the representatives of the liberal movement in Sweden, Johan Gabriel Richert, published alongside baron C. H. Anckarsvärden The Proposals of the National Representantion, a programme that put forth the idea of an unicameral parliament with two departments, following the model of the Norwegian Storting, nominated through general elections based on a minimal census. One of the enthusiastic propagandists of the new liberal ideas was Lars Johan Hierta, who edited works that endorsed the interests of the industrial and commercial circles. Then, in June 1830, he started editing the magazine

\footnotetext{
${ }^{4}$ Zigmantas Kiaupa, Ain Mäesalu, Ago Pajur, Guntis Vilumsons, The History of the Baltic Countries (Tallinn: Avita, 2000), 110-111.
} 
entitled The Evening Gazette, which enjoyed a large success and contributed greatly to the creation of the Swedish public opinion ${ }^{5}$.

From this perspective, therefore, the Swedish diplomacy approached, in its turn, the issue of the insurrection in Poland and Lithuania, closely watching their evolution and condemning them unreservedly. To this we must also add the fact that in the case of a victory of the insurrections, one of the first consequences would have been the radical upheaval of the ratio of forces in North-Eastern Europe, also affecting the Swedish political-institutional system, since it was to be assumed that the Norwegians would not have waited long before taking the Lithuanian and Polish examples and denouncing the personal union with Sweden. This is why the chargé d'affaires of Sweden in Petersburg, N. Fr. Palmstjerna, at the orders of the minister of Foreign Affairs of Sweden, Gustaf Wettrestedt, made it be known "l'impression pénible que le Roi a éprouvé en apprenant une nouvelle aussi chagrinante pour l'Empereur, que l'était celle de la révolte de Pologne" to the vice-chancellor of Russia, Karl (Charles) Robert Vasilievici Nesselrode (my Italics.) ${ }^{6}$. On that occasion, however, the Swedish diplomat noticed that the vice-chacellor of Russia "connaissait déjà, par les rapports du Général de Suchtelen, quels étaient les sentimens manifestés par Sa Majesté à cette occasion facheuse" (my Italics) ${ }^{7}$.

The Swedish authorities were left with the same 'feeling of distress' upon the outbreak of the insurrection in Lithuania, on 25 March 1831, whose evolution was closely watched, as already mentioned, by their diplomatic representative in Petersburg, N. Fr. Palmstierna. He noticed that the Russian military authorities in Lithuania had undertaken a number of measures meant to prevent the outbreak of the insurrection as early as the beginning of March 1831, among which the dislocation of part of the Lithuanian nobility inside Russia 8. Despite all the precautions, the outbreak of the insurrection could not be avoided. Thus, according to data he had come across and that he forwarded to Stockholm, on 6 April / 25 March 1831 an uprising occurred among the peasants of Samogitia, triggered by the recruitments to the Russian army and the financial obligations - the costs of the said army's transportation - imposed on the people by the tsarist authorities. Among the remarks recorded was the one that the Samogitian population was not of Polish origin, but spoke another

\footnotetext{
${ }^{5}$ Adam Kersten, Historia Szwecji (Wrocław-Warszawa-Kraków-Gdask: Zakład Narodowy Imienia Ossolińskich Wydawnictwo, 1973), 309.

${ }^{6}$ His report of January 8, 1831/December 27, 1830, to Gustaf Wetterstedt.

${ }^{7}$ Ibid.

${ }^{8}$ See his report of March 12/February 28, 1831. 
language, different from Polish. He also informed of the fact that the Russian authorities were not the only ones to take action in order to prevent the uprising from spreading: the nobility in Courland was taking arms to defend the same objective. Nevertheless, he was of opinion that, for the time being, the consequences of this new 'revolutionary infamy' would go no further than slight local damage and the momentary interruption or disturbance of the lines of communication, as "comme il en arrive toujours, au malheurs qui retomberont sur les coupables et sur les pauvres dupes" (my Italics) ${ }^{9}$. His attitude towards these disturbances is well illustrated by his statement that the measures ordered by the tsar to smother the riots were salutary, albeit barely short of atrocity ${ }^{10}$. By furthering his investigations on the Samogitian uprisings through the request of information from the vicechancellor of Russia, he was highlighting the direct connection between the Lithuanian insurrection and the Polish one, since it was believed that both had been caused by secret Polish emissaries who were connected to the local Lithuanian nobility, pointing towards the areas the insurrection had already spread to ${ }^{11}$.

His antipathy towards the insurrection is evident from the plethora of information regarding the Russian troops mobilized against the insurgents and their collaboration with a part of the Lithuanian nobility, but also from the phrases he used to refer to them and their initiatives, such as "mutins" and 'insolences'12, respectively. To the same effect was Palmstjerna's approval of Russia's stance regarding the Polish insurrection, in the sense that he refused to consider a French initiative concerning the adoption of some sort of truce by claiming that that particular case was no longer a mere riot, but a full war against Russia. But the victories the Polish insurrection was scoring at the time were seen as the main cause of the generalization of the insurrection in Lithuania ${ }^{13}$. Russia reacted to the phenomenon with genuine cruelty, a cruelty the Swedish diplomat approved of, though, considering it effective ${ }^{14}$. Since, according to him, the insurrection in Lithuania was "un malheur incalculable"; even more so as, despite the reprisals of the Russian authorities, the insurrection would break again as soon as the Russian troops left an area they thought of as pacified 15 .

\footnotetext{
${ }^{9}$ His report of April 6/March 25,1831.

${ }^{10}$ Ibid.

${ }^{11}$ His report of April 9/March 28, 1831 and the annex to the report, of the same date.

${ }^{12}$ See his report of April 16/4, 1831.

${ }^{13}$ See his report of April 30/18, 1831.

${ }^{14}$ His report of May 4/April 22, 1831.

${ }^{15}$ His report of May 21/9, 1831.
} 
Thus, by the end of May 1831, the Lithuanian insurrection had generalized. Since our intention was to signal only the information pertaining to the circumstances of its outbreak and its first phase of development, we have not selected the data that allows assessing the opinion of the Swedish diplomat, N. Fr. Plamstierna, on the events that took place in the following period, the one that ended with the defeat of the insurrection. The limited space we have at our disposal, as well as the fact that many of the discussed reports contain a vast array of information that does not bear any direct connection with our purpose, persuaded us to extract from those documents only the paragraphs we have a particular interest in.

The documents were selected from the Sveriges Riksarkivet, Kabinettet/UD Huvudarkivet, E2D, 702, the Petersburg fund, 1821, Jan.-iuni, both originals and copies, written, in both cases, in French, the diplomatic language of the time. They were transcribed so as to match the originals, with care - to the extent to which it was possible to do so - to observe the original punctuation, orthography and syntax. The phrase "sic!" was used each time we had to transcribe a phrase or a word as it appeared in the text, albeit incorrectly spelled or when we were unable to determine its meaning. We should also mention that the documents from this source are not paginated. Lastly, we would like to add that each document is preceded by a regest, and where the text required, by explanatory notes.

By introducing them to the scientific circuit, we express our belief that they will contribute, corroborated with other documentary or historiographic sources, to the expansion of the horizons of research in the history of North-Eastern Europe from the first half of the $19^{\text {th }}$ century.

\section{1}

Petersburg, March 12/February 28, 1831

N. Fr. Palmstjerna, the chargé d'affaires of Sweden at Petersburg, to Gustaf Wetterstedt, minister of state and minister of Foreign Affairs of Sweden

The dislocation of a part of the Lithuanian nobility inside Russia, to the effect of preventing the outbreak of disturbances in Lithuania; disputes at the upper level of command of the Russian army operating against the Polish insurgents; causes.

Apostille de Mr. le Baron de Palmstjerna, en date de St. Petersbourg du 12 Mars/ 28 Fevrier 1831 
Il me revient de bonne part, que indépendamment des changemens opérés dans le personnel du corps des Officiers de l'armée de Lithuanie, on s'est vû obligé à éloigner plusieurs propriétaires domiciliés dans ce pays, à fin d'en garantir la tranquillité. On les a fait partir pour les gouvernemens intérieurs.

On prétend, que le départ du Grand Duc, qui doit avoir quitté l'armée, aurait été motivé par une vive explication avec le Maréchal, au sujet de l'emploi du régiment d'Uhlan de S. A. Impériale lors de la bataille du 25. Ce Régiment favori, ayant donné avec beaucoup de bravour (sic !), a éprouvé une perte notable.

Sveriges Riksarkivet, Kabinettet/UD Huvudarkivet, E2D, 702, Petersburg, 1831, Jan.-iuni; copy in French language.

\section{2}

Petersburg, April 6 / March 25, 1831

N. Fr. Palmstjerna, to count Gustaf Wetterstedt

According to information received from Courland, and not from Vilno, as was expected, a riot had broken out in Samogitia among the peasants in the area; possible causes; the evolution of the riot; the remark that the Samogitian population was not of Polish origin, but spoke a language different from Polish; news was circulating about the measures undertaken by the Courland nobility to prevent the spread of the riot to the area; military action undertaken by the Russian authorities; his opinions on the military force the Russian authorities could oppose to the insurgents, as well as to the consequences "cette nouvelle infamie revolutionnaire", as he called the Lithuanian insurrection, could trigger; he then informed of tsar Nickolai I's ukaz, addressed to the Senate of Russia, which specified "avec une séverité salutaire", he thought, the measures to be resorted to in order to repress the riot; the difficulties that could have prevented the progress of military operations meant to repress the insurrection; his hopes that the insurgents would soon be defeated. 
Depuis mon dernier très-humble rapport du 2 Avril/21 Mars j'ai eû l'honneur de recevoir les ordres que Votre Excellence a bien voulu m'adresser en date du 25 Mars.

Dans un moment où la malveillance active des ennemis de l'ordre cherche à répandre partout les bruits faux ou exagérés, je ne crois pas devoir attendre la poste du Samedi pour rendre compte à Votre Excellence de ce que l'on sait ici, dans le public, sur une révolte qui vient d'éclater dans une partie du Gouvernement de Wilno. Je crains que peut-être des informations, venant par quelque autre canal, ne réprésentent la chose comme beaucoup plus dangéreuse qu'elle ne parait l'être jusqu'à présent. Je prends ainsi le pati d'en écrire par la Poste d'aujourd'hui qui va jusqu'à Äbo, en priant Monsieur de Fordelles d'expédier une estaffette.

La mutinérie a éclaté parmi les paysans de la Samogitie, dans les cercles de Telsch, Schawly et Rossieni; le recrutement et les charges à supporter pour les transports à l'usage de l'Armée paraissent avoir servir de pretexte pour les exciter. On parle aussi d'une dispute entre des Officiers Russes et de jeunes Polonais dans le théatre d'amateurs d'une petite ville. Quelques Gentilhommes, qui indubitablement sont les instigateurs, doivent se trouver à la tête de ces rebelles; mais les informations sont encore, pour autant que je sache, d'autant moins complètes, qu'elles viennent du Gouverneur de Courlande et non de Wilna, où selon les rapports officiels que l'on avait hier, tout était encore tranquille.

Comme cette Province (la Samogitie) était pour le moment dégarnie de troupes, les mutins ont eû beau jeu. On dit qu'ils ont fait prisoniers plusieurs Officiers du Département des vois de communication, employés dans cette contré pour les travaux du canal de Windau, et qu'ils ont pillé une caisse. Comme les attroupemnens étaient nombreux et qu'ils menaçaient Polangen (sic !) à une distance assez rapprochée, un Courrier Francais, arrivé hier et qui a eû quelque embarras pour passer, a trouvé les Autorités de cet endroit en retraite. Il ne doit y avoir eu qu'environ 150 Cosaques, qui, au besoin allaient également se retirer sur Memel. Il y a aussi des lettres de ce dernier endroit, qui est dans la proximité de ces troubles.

Il faut observer que le peuple dans la Samogitie n'est point Polonais. Il parle une langue particulière.

On dit (s. a.) qu'en attendant l'arrivée des troupes, la Noblesse voisine en Courlande s'arme pour sa défense et pour celle de l'ordre public, contre les mutins. 
$\mathrm{Au}$ reste, tous les ordres nécessaires on été donné sur le champ pour faire marcher des troupes. On peut tirer de l'Infantérie tant de Dünabourg que des Provinces Baltiques, où se trouvent les Bataillons de reserve du 1er Corps. Il est plus difficile de trouver la Cavalerie dans le voisinage ; cependant on dispose de 2 Regimens de Cosaques. Au besoin, d'ailleurs, les queues de Colonnes du $2 \mathrm{~d}$ Corps et de celui de la Garde pourraient faire volte face, sans causer aucun affaiblissement, préjudiciable à l'Armée, dont le nombre, dit-on est calculé maintenant jusqu'à 220,000 hommes. J'espère ainsi que l'on peut être tranquille sur les conséquences de cette nouvelle infamie révolutionnaire. Elles se borneront à quelques dommage locale, à l'interruption momentanée ou à la gêne de quelques communications et, comme il en arrive toujours, aux malheurs qui retomberont sur les coupables et sur les pauvres dupes, Il serait possible (s. a.), à la vérité, que la poste d'Allemagne fût interuptée (sic !) pendant quelque peu de tems.

Par le courrier ordinaire prochain, j'espère pouvoir transmettre des notions plus authentiques, si non plus circonstanciées. En attendant, Votre Excellence trouvera ci-près la traduction d'un Oukaze, qui vient d'être adressé au Sénat, et qui ordonne, avec une séverité salutaire, les mesures faites pour reprimer ces désodres.

Par la traduction ci-jointe d'un Bulletin2, qui encore n'a été publié qu'en Russe, Votre Excellence verra quelles sont les dernières nouvelles de l'Armée. Les boues horribles de la Pologne, que Napoléon appelait un 5me élément, forment un obstacle à toutes les opérations, le debordement de la Vistule en a présenté un autre, mais le moment approche, je l'espère positivement, où ils seront tous vaincus.

Je suis avec un profond respect

Monsieur le Comte

de Votre Excellence

le très-humble et très obeissant serviteur

N. Fr. Palstierna

S. E. Mr le Copt de Wettersted, Min. d'Etat et d'Aff. Etr.

Sveriges Riksarkivet, Kabinettet/UD Huvudarkivet, E2D 702, Petersburg, 1831, Jan.-iuni; original in French.

Petersburg, April 9 / March 28, 1831

N. Fr. Palin to count Gustaf Wetterstedt 
Military manoeuvres of the Russian troops; requests data on the uprisings in Samogitia to the vice-chancellor of Russia; it was thought that the rebellion had been caused by secret emissaries from the kingdom of Poland who were connected to the local Lithuanian nobility; a few leaders of the insurrection are named; a conspiracy meant to trigger the simultaneous outbreak of an insurrection in Vilnius is dismantled, and on the the same occasion two of the conspirators are arrested; additional information on the outbreak and evolution of the insurrection in Lithuania, among which the constitution of military detachments by the nobility in Courland and on the manoeuvres of the Russian troops responsible with the smothering of the insuurection; the intention of the ambassador of France in Petersburg to convince the Parisian public that the disturbances in Lihuania were of a local nature only;

In the Annex: general data on the issue of Luxembourg; new disturbances in Lithuania, caused by the secret partisans of the Warsaw emissaries; the close connection between the insurrection in Poland and that in Lithuania started to take shape, indicating the conflict-stricken areas; news that the Lithuanian rebels disposed of cannons the inhabitants had kept hidden that might have dated back to the French-Russian war from 1812; the possible numbers of the military organized peasants; the confiscation, from the order of the Russian general Kropovitki, of all tools liable of being used as weapons by the townspeople of Vilnius.

St Petersbourg le 9 avril/28 mars 1831.

\section{Monsieur le Comte}

Les derniers ordres de Votre Excellence sont en date du 25 Mars ; mon dernier très humble rapport fut transmis à Monsieur de Forschelle par la poste du $6 \mathrm{n}$. st. et avec l'ordre de l'expédier par estafette, s'il y avait moyen d'en faire passer

Par mon rapport du 2 n. st., j'ai eû l'honneur de mander à Votre Excellence que j'avais communiqué à Monsieur le Vice-Chancelier la lettre, adressée d'une main Auguste à un correspondant de France et dont une Copie s'est trouvée jointe aux ordres de Votre Excellence en date du 18 Mars. Voici, Monsieur le Comte, les termes du billet par lequel elle m'a été renvoyée. "Sa Majesté l'Empereur en a pris connaissance avec un vif intérêt et retrouvé, comme dans les précédantes, des observations d'une profonde justesse. Dieu donne que des vérité aussi frappantes, des conseils si salutaires portent fruit, et on peut affirmer hardiment que l'Europe sera préservée de plus affreuses calamités ». 
Il m'a été positivement assuré qu'à Cronstadt on est déjà occupé à équiper les batimens destinés au voyage que Madam la Grande Duchesse Helène va faire, selon la préscription des Médécins, pour aller prendre les bains de mer en Angleterre. D'après ce qui m'a été dit, l'on prépare une Frégate, un batiment de guerre moindre et une pyroscophe. L'on assure que Son Altesse Impériale sera accompagnée de Madame la Contesse de Nesselrode et du Chambellan Prince Gagarin.

Depuis ma dernière aucune nouvelle de l'Armée n'a été publiée : mais je tien de Monsieur le Comte de Nesselrode que le Maréchal allait commencer son mouvement général le 30/18. Il ne serait pas absolument impossible que Nous eussions la nouvelle du passage encore aujourd'hui.

J'ai demandé et obtenu la permission de passer chez Son Excellence hier, àfin d'apprendre si le Gouvernement possédait quelques notions authentiques et plus spéciales sur les troubles de la Samogitie, mais les rapports sont encore peu complets, l'action des Autorités étant paralysée dans les districts insurgés.

On croit, sans les savoir bien positivement que ce sont des émissaires venus clandestinement du Royaume, qui ont saisi l'occasion du recrutement pour provoquer le peuple à la rébellion, à l'aide des intelligences qu'ils avaient parmi la Noblesse du pays. On raconte aussi que le Général Comte Paç, qui est possessionné (sic !) en Lithuanie, serait à la tête du mouvement, mais le Comte de Nesselrode n'était pas trop disposé à croire ce bruit fondé. Parmi les autres Chefs, on nomme un Comte Zaluski et un Monsieur Narbut, Gentilhomme Lithuanien.

Il parait certain, que le projet était formé pour opérer simultanement une revolte à Wilna, mais le Général Khrapovitzky, qui ne doit ni ne plaisante (sic !), a découvert et déjoué cette conspiration. Il a fait arrêter plusieurs individus, parmi lesquels le Maréchal de la Noblesse, le même Monsieur Gorski, qui naguères a signé une adresse, remplie de protestations de loyauté et de dévouement! Cette arrestation est un fait positif, qui m'a été communiqué par Monsieur le Vice Chancelier.

Il y a maintenant quinze jours, au plus, que les premiers mouvemens ont commencé, mais l'on ne connait pas exactement l'historique des opérations que les rebelles ont entreprises. On sait cependant qu'ils ont forcé les gardes des douanes, sur la frontière, depuis Yourbourg jusqu'à Polangen, à se retirer sur le territoire Prussien. On avait espéré que ces Gardes, qui sont au nombre de 250 hommes armés et qui avaient l'ordre de se réunir à Polangen, à mesure que l'insurrection avancerait sur eux, auraient pu tenir dans cet endroit ; mais cela n'a pas été le cas, puisque les deux postes d'Allemagne, qui auraient dû arriver par 
cette route hier et avant-hier, nous manquent, celle de Meitau étant arrivée. Une Estafette, expédiée de Memel, a passé, mais elle avait été visité par une troupe de paysans.

Dans une douane, qui, si je ne me trompe, est à Gorschdy (Garsden) les rebelles se sont livrés à différens excès, avec une brutalité féroce. Ils ont paru aussi en dedans de la frontières de (l'ancienne) Courlande, nommement dans une terre du Comte de Medem ; mais là ils n'ont fait aucun dégat. En attendant, il est vrai que la Noblesse de Curlande a formé de ses gardes chasse un Corps de 5 à 600 hommes, et qui peut-être pourra être porté jusqu'à 1000. Cette troupe, composée d'excellens tireurs, pourra rendre de bons services.

Le Baron de Pahlen, Gouverneur Général des Provinces Baltiques, est en marche avec 3 Bataillons, mais que je suppose être des bataillons de reserve du Ier Corps et par conséquent non complets. Il a aussi mené avec lui 4 Canons, pris à Riga et commandés un Officier d'Artillerie de l'Armée de Caucase, qui par hazard s'y trouvait en semestre.

$\mathrm{Au}$ reste, de tous les cotés on fait marcher des troupes plus nombreuses pour étouffer cette révolte. Il en arrive de Novgorod et de Kowno. La force sera d'autant lus suffisante, que les rebelles ne peuvent être que très mal armés.

Quant à la poste, on a pris des mesures pour la transporter par mer entre Memel et Liebau, pourvu que les rebelles ne penetrent pas jusqu'à ce port, où il n'y aura guères (sic !) de troupes, qui n'est pas très éloigné de Polangen et ou l'appât du pillage pourrait les attirer.

Malgré qu'ainsi les communications directes soyent en ce moment précaires, l'Ambassadeur de France expédie aujourd'hui un Courrier ; mais il a paru indécis sur la route à choisir. Comme néanmoins les Courriers doivent toujours trouver moyen de passer, quand même ce serait par un detour, l'Ambassadeur parait se proposer d'en faire partir successivement plusieurs, àfin (sic !) de prouver au public de Paris que l'insurrection est seulement locale.

Sveriges Riksarkivet, Kabinettet/UD Huvudarkivet, E2D, 702, Petersburg, 1831, Jan-iuni ; original in French.

Annex

Apostille de Mr le Baron de Palmstjerna, en date de St Petersbourg, le 9 Avril/28 Mars 1831 
Il est peut-être connû à V. E., qu'il existe un vingtième protocôle de la conférence de Londres, mais qui n'est signé que par les Plénipotentiaires des 4 Puissances, à l'exclusion de celui de France.

D'après ce que l'on m'a dit, ce protocôle repond à quelques objections, qu'elle avait élevé contre les articles consignés dans les Protocôles précédens sous le nom de bases. D »après ce que j'apprends, ces objections se sont rapportées aux limites du Grand Duché de Luxembourg, et à la répartition de la dette publique, la France ayant soutenû, que la quote-part (sic !) du Grand Duché devait être defalquée de celle de la Belgique. Comme on m'a promis la pièce, il serait inutile d'entrer ici dans les détails, que je pourrai être dans le cas de devoir rectifier après l'avoir vû.

L'évenement justifie, par malheurs, les appréhensions éventuelles, que j'avais annoncé pour la tranquillité de la Lithuanie, au cas que la guerre se prolongeât dans le royaume de Pologne. C'est aux malheureux retards, causés par la saison qu'il faut attribuer ces nouveaux troubles excités par les émissaires et les adhérans secrets des émissaires de Warsovie. Dieu veuille, que la révolte se borne à la Samogitie. Jusqu'à présent l'on n'apprend pas , qu'elle se soit répandû hors du Gouvernement de Wilna, et la présence des troupes dans les autres provinces, fait esperer, qu'elles resteront tranquilles. On prétend, qu'en dernier lieu le general Khropowitzky a crû devoir prendre la précaution de désarmer les habitans de Wilna, et qu'il l'a fait tellement, à la lettre, qu'il n'a laissé qu'une seul hache à l'usage des deux maisons.

Quelqu'un m'a assuré que les rebelles ont des cannons. Ne comprenant point comment ils leur seraient parvenûs, l'on suppose, qu'ils ont pû être ramassés parmi les débris de 1812, et cachés depuis cette époque ; chose qui ne serait pas impossible. L'on prétend aussi, que le nombre des paysans auxquels les chefs ont taché de communiquer une espèce d'organisation, s'éleverait jusqu'à 12,000.

Sveriges Riksarkivet, Kabinettet/UD Huvudarkivet, E2D, 702, Petersburg 1831, Jan-iuni, copy in French.

Petersburg, April 16/4, 1831

N. Fr. Palmstjerna to count Gustaf Wetterstedt 
Official details pertaining to the disruptions in Samogitia, still unvailable; Russian infantry and cavalry troops massed in the surroundings of Vilnius, some of them transferred from Cuban; additional data on the numbers of the Russian troops massed against the insurgents, joined by the military force offered by the nobility in Courland and Latvia; various statements of the leaders of the Lithuanian insurrection; the peasants enrolled in the insurgent troops refuse to fight the Russian troops; symptoms of the cholera epidemic in Moscow and Minsk; military governors named in Minsk and Riga.

St. Petersbourg, le 16/4 Avril 1831

Monsieur le Comte

Les nouvelles sur les troubles de la Samogitie ne sont officiellement connues, dans le public, que par l'Article inséré dans l'une des feuilles cijointes . En général, on m'assure que ces nouvelles sont maintenant beaucoup plus rassurantes. Il est positif que la route de Polangen est débloquée ; les malles, qui manquaient lors de ma dernière, ont été transportées par Mer de Memel à Liebau, mais celle d'hier doit être venue par la route de terre, comme sont arrivés le Comte Apraxin et un Courrier Français. L'on dit que le passage, exposé aux attaques, est à présent garni par un Corps de 1500 hommes. On ajoute que déjà il était arrivé aux environs de Wilna un renfort d'Infantérie et de Cavalerie irrégulière, venant de l'intérieur ; parmi cette dernière, il y a un Poulk de Cosaques et un Poulk de Teptiaires, arrivés d'Orenbourg, ainsi qu'un Poulk des Cosaques dits Grebenskié, tirés de la ligne du Couban.

La principale force, destinée contre les rebelles, se compose de 18 Bataillons de Grénadieres, qui etaient restés dans les Colonies de Novgorod et dont une grande partie est transportée en chariots. On dit aussi que la Noblesse de Livonie, selon l'exemple de la Courlande, a offert d'armer 3000 hommes.

On ne connait pas encore le sort de 8 Officiers du Corps des voies de communications, qui lors de la première bagarre sont tombés entre les mains des rebelles. À cette occasion, ils se sont emparés d'une provision modique de poudre et d'une quantité plus considérable de plomb et de fer, qui servaient aux travaux du canal. Ils ont aussi fait du dégât aux écluses.

Les Chefs de ces mutins avaient eû, d'après ce que l'on prétend, l'insolence de déclarer à leurs voisins, les Courlandais, qu'ils respecteraient leurs limites, mais que sous peine de confiscation! (s.a.) les Gentilshommes, 
possessionnés (sic !) en Lithuanie, devraient s'y présenter en personne. On voit que ce n'est point la hardiesse des paroles qui leur manque ; mais selon les lettres particulières, les paysans, qu'il ont attroupés, n'en ont guères pour battre. Ils prennent la fuite dès qu'ils rencontrent une force armée.

On avait eû, cependant, ainsi que j'ai eû l'honneur de l'indiquer, quelques apprehensions pour Liebau, où l'on avait pris toutes les précautions possibles; les propriétés de la Courrone avaient été embarquées. Dirigés par le Colonel d'Üxkull, maitre de Police de la Ville, les bourgeois s'y étaient armés et l'on avait débarqué les canons, trouvés à bord de quelques batimens marchands. Mais par suite des combats qui ont eû lieu près de Polangen, Liebau est couvert. La première de ces deux villes a été moins heureuse ; on m'assure que dans la dernière affaire, elle a été presqu'entièrement détruite par un incendie.

D'après les notions répandus hier au soir, il paraitrait que le foyer de l'insurrection se réduit actuellement à la ville et aux environs de Shawly.

Je suis bien faché de devoir ajouter aux données, qu'une feuille cijointe renferme au sujet du Cholera, celle que l'on a de nouveau observé des symptomes de cette épidémie à Moscou ; cependant il n'y avait eû que 4 personnes d'attaqués jusqu'à présent. On a aussi remarqué quelques symptomes suspectes à Minsk, où l'Empereur vient d'envoyer, en qualité de Gouverneur Militaire temporaire, Son Aide de Champ Général, le Prince Nicolas Dolgorucki, le même qui a été employé en Perse.

Le Général Comte Serge Stroganoff, de la Suite de l'Empereur, a été envoyé à Riga, pour y gérer les foctions de Gouverneur en l'absence du Baron de Pahlen.

Je suis avec un profond respect

Monsieur le Comte

de Votre Excellence

le très-humble et très-obeissant serviteur

N. Fr. Palmstjerna.

S. E. Mr le Cte de Wetterstedt. Min. d'Etat et des Af. Etr.

Sveriges Riksarkivet, Kabinettet/UD Huvudarkivet, E2D, 702, Petersburg 1831, Jan-iuni; original in French. 
N. Fr. Palmstjerna to count Gustaf Wetterstedt

Russia's refusal to consider the French idea of an international intervention in favour of the Polish insurgents, whose victories lay at the bottom of the outbreak of the uprisings in Lithuania; the latter's extent, that was likely to grow with the arrival in Lithuania of a Polish corps; a few Lithuanian nobles arm the peasants on their estates; the measures undertaken by the provisory insurrectional government of Telsz; other general data.

Apostille No 1 de Mr. le Baron de Palmstierna en date de St Petersbourg le 30/18 Avril 1831

Ayant faut part au Comte de Nesselrode de ce qui m'a été communiqué par l'Apostille de V. E. en date du 1 Avril, touchant le langage, qu'a tenu Mr. de Sebastiani , après avoir lû une lettre du Roi , j'ai trouvé, que Mr le Vice-Chancelier avait, comme V. E. de la peine à s'impliquer ce que le Ministère Français entend par les garanties (s. a.) qu'il désire. J'ai suggéré l'idée que le désarmement général, dont les autres Puissances donneraient l'exemple, pouvait être l'objet de ce désir : mais le Comte observa, avec raison, que les evenemens de la Pologne n'ont que trop justifié les précautions prises par la Russie : que s'il y avait un reproche à lui faire, se serait plutôt celui de n'y arriver pas mis encore assez de promptitude et d'étendue : enfin, que cette même cause, quant au moment, met la Russie hors de la question pour ce qui regarde les armemens. "Le fait est » me dit le Comte, «que à l'époque de la revolution de Paris, nous étions profondement paisibles, et que, maintenant, il y a par-tout (sic !) des troubles, parmi lesquels ceux de Pologne sont devenus une guerre veritable",

D'après ce que je crois savoir, la Maréchal Diebitsch a écrit à l'Empereur, qu'il n'ignore point la critique, dont il est l'objet à St Petersbourg : mais qu'il supplie Sa Majesté d'attendre l'issue finale de la campagne, avant de le juger sur ces accusations.

Nous connaissons déjà l'impression, qu'a pruduit à Paris la nouvelle des derniers succès des Polonais : l'Ambassadeur lui-même parait envisager le retard des opérations, et les entraves qu'elle trouveront, comme le plus grand obstacle, qui puisse s'opposer aux intentions sincèrement pacifiques de son Gouvernement.

V. E. sait, que les troubles de Lithuanie doivent être attribués à la même cause. Je crains, qu'ils ne soyent pourtant plus menaçants, que ne le portaient mes dernieres informations. L'avant dernier rapport du Comte 
Diebitsch le fait déjà suspecter : maintenant venons de voir une tourbe de rebelles à Oschmiana entre à Wilna et à Minsk : ce plus là la Samogitie. En outre, il me revient de nouvelles particulières, mais assez directes, suivant lesquelles l'insurrection embrasse avec plus au moins d'intensité la presque totalité du Gouvernement de Wilna ; si l'on ne s'est pas encore formellement armé, par-tout (sic !), il doit être certain, qu'au moins, on n'attend que l'arrivée d'un Corps Polonais pour se soulever. Si le Général Uminski, dont les mouvemens paraissent trahir ce projet, reussissait à pénétrer jusqu'en Lithuanie, il est à craindre, que l'affaire ne devienne d'autant plus serieuse, que l'on continue à parler, avec quelque inquiétude la fermentation, qui regne aussi dans le Gouvernement de Minsk, et dans celui de Witepsk, où l'introduction recente des lois russes n'a point servi à diminuer le mécontentement de la noblesse. Dans toutes ces provinces, il parait être partagé par deux classes influentes : le clergé, et les juifs.

Il y a quelque tems avant l'arrivée des renforts, que, d'après ce que l'on prétend, les villes de Wilna et de Wilkomirz étaient presque les seuls points du Gouvernement de Wilna, qui fussent bien assurés, moyennant leurs Garnisons, et la capitale notam[m]ment par l'énergie et les menaces du Général Kropowitsky. Depuis peu, on me dit, cependant, que le depart de Mr de Novosiltzoff a contribué a calmer les esprits à Wilna même.

Le premier proprietaire, qui armà ses paysans, s'appelle, dit on, Ruszewski. Le prétendu Gouvernement provisoire à Telsch, a prononcé la confiscation des grandes possessions de la famille Zoubov en Samogitie, vû qu'elle ont appartenu, jadis, à la couronne de Pologne, et qu'elles en auraient été illégalement aliénées.

$\mathrm{D}^{\prime}$ après ce qu'on m'a assuré une personne, à même de le savoir, il n'y avait point d'insurrection en Wolhinie, à l'époque du 13 Avril ; mais alors le Général Dvernicki venait d'y entrer.

L'envoi des vivres par mer à Danzic, était ordonné avant les troubles de Lithuanie; c'est un calcul d'économie, mais qui supposait l'occupation des bords de la Vistule.

J'ai vû une lettre d'un des principaux adhérens de la Reigne de Portugal, qui considère la cause de cette Princesse comme presque perdue. Il accuse amèrement le présent Ministère Anglais.

Lord Heytesbury , qui a demandé un congé, et avec instance, parait disposé à se retirer du service. J'ai tout lieu de croire, qu'il est fort peu satisfait de lord Palmerston : l'on prétend, même, que l'Ambassadeur s'est crû dans le cas de s'en plaindre directement auprès du Roi.

Sveriges Riksarkivet, Kabinettet/UD Huvudarkivet, E2D 702, Petersburg, 1831, Jan-iuni; copy in French. 
6

Petersburg, May 4 / April 22, 1831

N. Fr. Palmstjerna to count Gustaf Wetterstedt

The spread of the insurrection in Lithuania; bloody reprisals initiated by the Russian army; his opinion that these measures were effective; the Vitebsk nobility's refusal to sign a thank you address for the introduction of the Russian lawin Belarus; the state of the insurrection in Volhinia and Podolia; the consequences of the insurrection; his hope that the insurrection would be stifled.

St. Petersburg le 4 Mai/22 Avril 1831

Monsieur le Comte

Il parait de plus en plus se confirmer, que tout le Gouvernement de Wilna était prêt, naguères. à prendre les armes et il est clair qu'elles ont été prises dans d'autres districts que la Samogitie. Les insurgés d'Oschmiana formaient une bande à part. Je ne sais si les détails, que l'on raconte sur cette affaire, sont tous fondés ; mais on prétend (s.a.) que le Clonel de Cosaques du Caucase, qui commandait cette expédition, après avoir passé au fil de l'épée 3 ou 400 paysans et cerné le reste, ordonna à tous les Schlachcić et autres personnages de distinction (s.a.), de sortir de la foule : qu'ils en sont sortis au nombre de 150 : qu'à un signe donné, ils furent tous pendus sur le champ par les Cosaques, moyennant les lacets qu'ils portent toujours avec eux, suivant l'usage des Tscherkesses ; qu'ensuite les paysans ont reçu, chacun individuellement, un correction paternelle, composée de 100 coups de Nogaika; et qu'après avoir eû la tête rasée, afin d'être reconnus en cas de récidive, ils furent renvoyés chez eux. Des personnes bien informées soutiennent cependant que dans ce récit il y a exagération, surtout pou les nombre des pendus.

Quoiqu'il en soit, ces moyens sont efficaces ; mais c'est un terrible inconvénient, que d'avoir sur ses derrières un pays étendu où ils sont nécessaires. Dans le Palatinat d'Augustowe, les Gardes paraissent entourées d'insurrections; il y a eû une affaire, dans laquelle on a fait prisonniers plus de 1000 insurgés. Il me parait, de plus en plus, qu'on ne se fie pas trop à la tranquillité d'aucun des Gouvernemens ci-devant Polonais, 
à moins qu'elle ne soit militairement garantie ; le départ du Grand Duc Constantin, qui en effet doit avoir quitté Bialystok, parait prouver dans le même sens. Du Gouvernement de Mohilev il y a ici une députation, dont l'objet ne m'est pas encore exactement connu ; mais je sais que la Noblesse de Witepsk a décliné l'adresse de remerciement, que le Gouverneur Général, Prince Khawansky a voulu lui faire voter, à l'occasion de l'Oukaze pour l'introduction des lois Russes dans la Russie Blanch.

$\mathrm{D}^{\prime}$ après ce que l'on me dit, l'insurrection ne se repand en Volhinie, que sur le terrain que le General (sic !) Dvernicki peut occuper et encore la Noblesse y évite de se compromettre personnellement (s. a.). En Podolie, les biens d'un Comte Potocki (Frère de ceux connus de Monseigneur le Prince Royal) ont dû être séquestrés, lui-même se trouvant à Paris, où il donne, ainsi que sa femme, tout à fait dans la révolution.

$C^{\prime}$ est ainsi que la ruine des familles est l'une des conséquences désastreuses de ces troubles. La familles de Zoubow, qui possède de 40 à 50,000 paysans dans la Samogitie, en est spécialement victime; le Gouvernement provisoire s'est emparé des terres, et les administre à son profit, tandis que les paysans tombent sous le fer des Soldats, ou seront soumis à la vindicte des lois. Les personnes, connus chez nous, dont la fortune est ainsi compromise, sont : Madame la Comtesse Paul de Suchtelen, née Zoubow, et surtout le beaufils (sic !) du Comte de Modène.

Neanmoins, je le repete, les moyens successivement réunis pour contenir ces provinces, sont puissans et j'éspère qu'ils suffirent pour $y$ retablir l'ordre. Une Division d'Uhlans, aux ordres du Prince Khilkoff et composée de 24 Escadrons, a dû être détachée, à cet effet, de l'Armée, et se trouve en ce moment près de Wilna : nouvelle preuve de l'état où y étaient les choses.

Je suis avec un profond respect

Monsieur le Comte

de Votre Excellence

le très-humble et très obéissant serviteur

N. Fr. Palmstjerna.

S. E. Mr le Cote de Wtterstedt, Min d. Etat et d'Aff. Etr.

Sveriges Riksarkivet, Kabinettet/UD Huvudarkivet, E2D 702, Petersburg, 1831, Jan-iuni; original in French. 


\section{N. Fr. Palmstjerna to count Gustaf Wetterstedt}

The attitudes of England, France and Prussia regarding the issue of the Polish insurrection; his opinion that the Lithuanian insurrection was "un malheur incalculable" that increased the difficulties that enabled its defeat; reprisals of the Russian troops, whose efficacy was only temporary; another opinion of his, according to which only a decisive victory of the Russians could restore order in Lithuania.

Apostille No 2 de Mr le Baron de Palmstierna en date de St Petersbourg le 21/9 Mai 1831

D'après tout ce que je parvient à apprendre, les Cour de Londres, Paris et de Berlin comprennent trop bien la position de l'Empereur, pour avoir tenté rien qui ressemble à une intervention dans les affaires Polonaises. Si l'on a touché à cette corde, comme cependant j'ai lieu de le croire, c'est avec le plus grand menagement, et en se bornant, pour ainsi dire, aux voeux généraux. On sent qu'afin (sic !) le pouvoir pardonner, il faut commencer par vaincre. Quant aux deux premiers Cours, elles ont fait sonder, toutefois les dispositions de l'Empereur par rapport au parti qui serait pris « après » avoir opéré la soumission des Polonais : question evantuelle et toute différente que les traités placent dans la compétence de toutes les parties contractantes au Congrès de Vienne. Je ne sais pas encore ce qui a été repondu.

Le seul moyen d'accommodement, qui, d'après ce que l'on soupçonne pourrait n'être pas envisagé ici comme absolument inadmissible, serait celui de charger par exemple la Cour de Berlin de donner sous main aux Polonais des assurances sûr la manière dont l'Empereur agirait envers eux en cas de soumission absolue. Mais toujours $\mathrm{y}$ aurait-il une espèce d'intervention et tout plein de difficultés. Dans l'état actuel des choses je ne prévois nullement qu'un tel projet puisse être serieusement conçu et moins encore exécuté,

L'insurrection de Lithuanie est un malheur incalculable, et les difficultés, pour en venir au bout, ont paru jusqu'à présent s'accroitre. V. E. voit qu'elle parait plutôt se repandre, qu'elle n'est étouffée. Il semble que maintenant les troupes Russes ont pénétré presque dans tous les districts revoltés : là où elles paraissent, les rebelles sont battues ; on en tue quelques fois beaucoup, et les autres alors, à moins qu'ils ne trouvent un refuge dans les bois, retournent tranquillement au labourage. Mais du moment que les 
troupes s'éloignent, la revolte éclate de nouveau dans les endroits qu'elle viennent de quitter ; et c'est un pays ainsi disposé que l'armée dépend pour ses subsistances et pour ses communications ! comme on ne publie que tout au plus un fait isolé, il nous est presque impossible de connaître l'etat des choses au juste : mais en ce moment toutes les notions qui nous parviennent concourent à le dépeindre comme inquiétant Quoiqu'il en soit, si l'on remportait une victoire décidée sur l'armée Polonaise, et si Varsovie était occupée, le reste ne tarderait apparemment pas à rentrer dans l'ordre ; mais quant aux remèdes topiques, le mal semble assez grave pour qu'ils puissent y resister longtems.

Sveriges Riksarkivet, Kabinettet/UD Huvudarkivet, E2D 702, Petersburg 1831, Jan-iuni; copy in French

\section{References:}

\section{A. Archives}

Sveriges Riksarkivet [Swedish National Archives], Kabinettet [Cabinet]/UD Huvudarkivet, E2D, 702, the Petersburg fund, 1821, Jan.-iuni.

\section{B. Books and articles}

Bamhauer, Hermann et al. bearbeiter, Illustrirte Weltgeschichte. München: Südwest Verlag, n.d.

Kersten, Adam. Historia Szwecji. Wrocław-Warszawa-Kraków-Gdask: Zakład Narodowy Imienia Ossolińskich Wydawnictwo, 1973.

Kiaupa, Zigmantas, Ain Mäesalu, Ago Pajur, Guntis Vilumsons. The History of the Baltic Countries. Tallinn: Avita, 2000. 